\title{
MYCORRHIZAL EFFICACY ON CHEMICAL COMPOSITION OF THE TEJETES ERECTA, L (Marigold)
}

\author{
R. K. Aher \\ New Arts, Commerce and Science College Parner, Dist- Ahmednagar, M S., India
}

Communicated : 19.02 .2020

Revision : 15.03 .2020 \& 25.4.2020

Accepted : 18.05 .2020

Published: 30.05 .2020

\begin{abstract}
:
Tajetes erecta (Marigold) is an hairy erect annual herb 1-2 ft high. It consists of chemical compositions like salicyclic acid, essenatial oil. Essential oil containing azulenogenic sesquiterpenes. Flowers contain calendulin, traces of essential oin, oleanolic acid, a gum, a sterol, cholesterol and arnidiol. Insulin in roots. This plant is vulnerary, astringent and styptic. Leaves are resolvent and diaphorties. Flowers and plant used to treat wounds and injuries hence this plant taken for experimental study. The purpose of this study was to observe effect of mycorrhizha on plants and its different biochemical composition. The leaves of Tajetes showed good antioxidant activity (82.17\%) and UV-Visible spectra shows growth factor of plant. These observations are suggested that use of mycorrizha for the growth of plant is useful and also shows positive impact on biochemical composition of plant Tajetes.
\end{abstract}

Key wards:- Mycorrhiza, Chemical composition, Tejestes erecta, L.

\section{INTRODUCTION:}

During the present investigation, effect of AM fungi on the growth of medicinal plants were studied. Medicinal plants like Tajetes erecta, L selected for the present study because they are common, seasonal and medicinally most important. Tajatus erecta is an hairy erect annual herb 1-2 ft high. It consists of chemical compositions like salicyclic acid, essential oil. Essential oil containing azulenogenic sesquiterpenes. Flowers contain calendulin, traces of essential oin, oleanolic acid, a gum, a sterol, cholesterol and arnidiol. Insulin in roots. This plant is vulnerary, astringent and styptic. Leaves are resolvent and diaphorties. Flowers and plant used to treat wounds and injuries hence this plant taken for experimental study. (Jain, 2008).

Due to number of medicinal properties Tajetes is selected for pot culture experiment. The purpose of this study was to observe effect of mycorrizha on plants and its different biochemical composition.

\section{MATERIAL AND METHOD:}

To test the effect of mycorrhiza on the chemical composition of the medicinal plant, plant extract prepared from the leaves and twigs of respective Tajetes plants after 40 days of sowing of the seedling.

\section{Analysis of Tajetes extract}

Sample Plantation and Collection - The purpose of this study was to observe effect of mycorrizha on plants and its different biochemical composition. Tajetes sample was planted in soil of Parner (Ahmednagar, Maharashtra) in period of June - July 2018, and grows under observation. Plants grow in soil which contains mycorrizha (Experimental) and another one (Control) is grows under normal soil condition.

Sample Preparation - Tajetes leaves taken and clean by using distilled water and dried using distilled water. Exactly $1 \mathrm{~g}$ of leaves weighed and taken into motor and pestle and prepared paste of it. Paste was transferred into solvent extraction cell and added $50 \mathrm{ml}$ methanol and extracted twice. Collected 
extract into $100 \mathrm{ml}$ volumetric flask and make up final volume to $100 \mathrm{ml}$ with methanol.

\section{Plant Extract}

Di phenyl picryl hydrazyl (DPPH) assay was performed according to recommended Methods of and Interpretation Measurement mentioned by Philip Molyneux.

Each plant extract sample's stock solution $(1 \mathrm{mg} / \mathrm{ml})$ was diluted to final concentration of $1000 \mu \mathrm{g} / \mathrm{ml}$ in methanol. Volume was made up to $2 \mathrm{ml}$ with methanol. 2 $\mathrm{ml}$ of $0.004 \%$ of DPPH was added to the sample solution. These were test samples. $2 \mathrm{ml}$ of methanol was added to the sample solution of different concentration. These were blank solutions. $2 \mathrm{ml}$ of DPPH solution was added to $2 \mathrm{ml}$ of methanol and used as negative control. The blank for this solution was methanol. Similarly, ascorbic acid as DPPH is sensitive to light, it was exposed to the minimum possible light. These solutions were kept at room temperature in dark for $30 \mathrm{~min}$ to complete the reaction (Shamim et al., 1994). The absorbance was measured at $518 \mathrm{~nm}$ and converted into the percentage antioxidant activity using the following equation:

Scavenging capacity $(\%)=$

(Absorbance of negative control - Absorbance of test) $* 100$ Absorbance of negative control

\section{RESULTS AND DISCUSSION}

During result we have observed UV-Visible

Spectroscopic analysis and anti-oxidant activity

UV-Visible Spectroscopic Analysis of

Tajas and its interpretation

The UV- Visible Spectra of Tajetes shows absorption at $543.6 \mathrm{~nm}$ shows it contains Chlorophyll-a, for experimental sample extract it contains absorption of 0.8437 and that of control sample is 0.605 , absorption at $613.3 \mathrm{~nm}$ corresponding Chlorophyll-b, for experimental extract it contains absorption of 0.9024 and that for control sample is 0.7852 , and absorption at $668.2 \mathrm{~nm}$ also corresponding to Chlorophyll-a, for experimental extract it contains absorption of 2.130 and that of control sample is 1.019 , it clearly shows that impact of sunlight on formation of these biochemical substances in the Tagetus plant (Karthikeyan et al., 2009).

Antioxidant Analysis of Tagetes and its interpretation

\section{CONCLUSION:}

The plant extract of Tagetes treated with mycorrhiza showed good antioxidant activity (72.85 and UV-Visible spectra shows growth factor of plant. These observations are suggested that use of mycorrizha for the growth of plant is useful and also impact on biochemical composition of plant Tagetes as compared to control. Our results correlate with Marieta et al., (2017) the greatest increase in the total esterase activity and concentration of phenols, flavonoids and ascorbate was marked in the plants with simultaneous inoculation of mycorrhizal fungi and the green algae. Assay proved the increased plant antioxidant capacity after co-colonization of green algae and mycorrhizae.

\section{REFERENCES:}

Akerele, O., Heywood, V. \& Synge, H. (Eds). 1991. Conservation of medicinal plants. Cambridge University Press, Cambridge.

Adholeya, A. and A. Gaur. 1994. Estimation of VAM spores in soil: a modified method. Mycorrhiza News. 6(1) : 1011.

Jain, S K . 1991. Dictionary of Indian Folk Medicines and Ethnobotany, Deep publication, New Delhi.

Joshi, S.G. 2006. Medicinal Plants. Oxford and IBH Publishing Company Private Limited, New Delhi. 
Karthikeyan B., M. M. Joe1 and C.A. Jaleel. 2009. Response of Some Medicinal Plants to Vesicular Arbuscular Mycorrhizal Inoculations. J. Sci. 1 (1) : 381-386.

Karthikeyan, B., M. M. Joe and C.A. Jaleel.

(2009). Response of some medicinal plants to vesicular arbuscular mycorrhizal inoculation. J. Sci. Res.1(1): 381-386.
Shamim, D., Ahmed, T., Ayub, N. 1994. Influence of seasonal variations of VAM infection in perennial plants. Pakistan Journal of Phytopathology 6(2) : 77-86.

Verkade, S.D., Elson, L.C. \& Hamilton. D.P. 1988. Effect of inoculation on growth following transplanting of Cornus sericea cuttings and seedlings. Hort. 227

\section{Antioxidant activity-}

a) DPPH assay:

\begin{tabular}{|c|c|c|c|c|c|c|}
\hline \multirow[b]{2}{*}{ Sample/Experimental } & \multicolumn{6}{|c|}{$\%$ inhibition at Time (min) } \\
\hline & 5 & 10 & 15 & 20 & 25 & 30 \\
\hline Tagetes Experimental & 50.97 & 54.62 & 58.67 & 63.53 & 67.18 & 72.85 \\
\hline $\begin{array}{c}\text { Tagetes Control } \\
\text { Sample }\end{array}$ & 33.14 & 35.58 & 41.25 & 46.11 & 52.59 & 57.05 \\
\hline Ascorbic acid & 74.88 & 77.71 & 79.34 & 80.15 & 82.29 & 87.03 \\
\hline
\end{tabular}

SYSTRONICS

DOUBLE BEAM UV-VIS Spectrophotometer: 2202

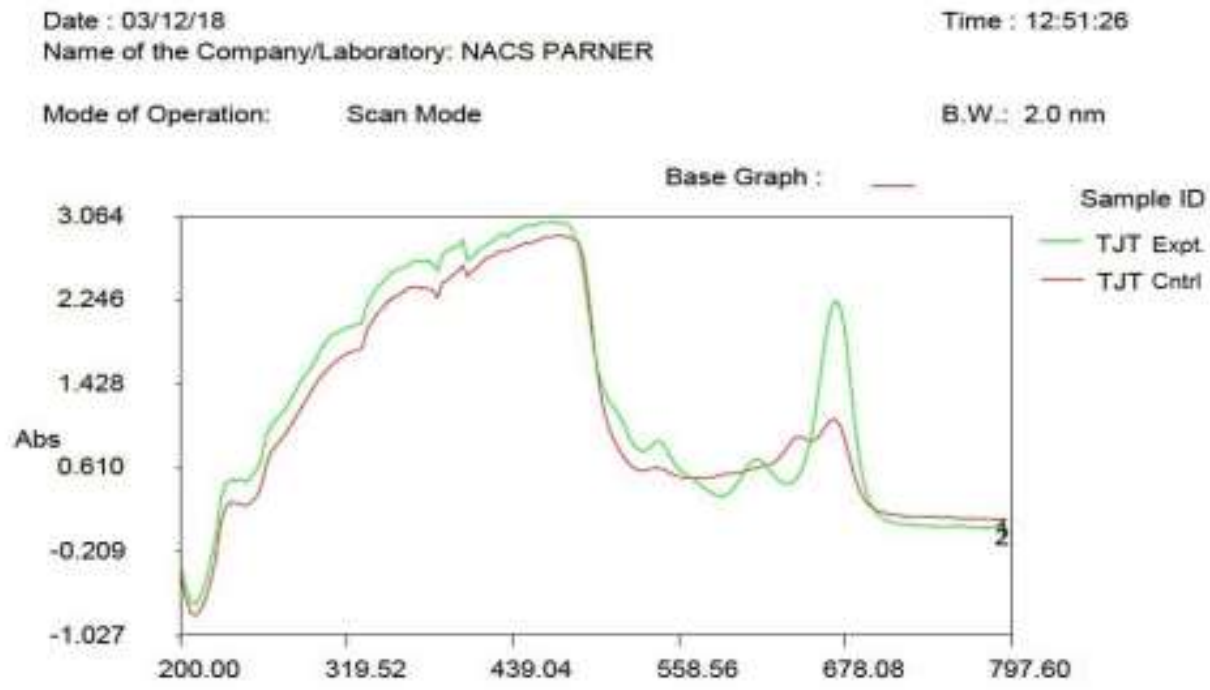

